\title{
ANALISIS TINGKAT PERMINTAAN PEMBIAYAAN \\ PADA BANK UMUM SYARIAH DI INDONESIA \\ PERIODE 2006 - 2010
}

\author{
Oleh: \\ Dewi Jannatul Firdausiyah \\ Staff PT. Bank BTPN Syariah Probolinggo \\ E-mail/No. Hp: Dj.firdausiyah@gmail.com/-
}

\begin{abstract}
This study was a descriptive quantitative type of research which was conducted at 5 Islamic banks in Indonesia, entitled "The Level of Demand for financing Analysis at Islamic Banks in Indonesia Period 2006-2010”. From the results were obtained the coefficient of determination (R2) for panel data of regression model Random effect of 0.89. This means that the independent variables together were able to explain that $89 \%$ were variation in dependent variable, namely the financing demand. From the data analysis which had conducted simultaneously showed that the variable of income per capita and the profit sharing ratio had a more significant outcome of the financing demand than the variable of lending rates for working capital. It could be seen from the probability or significance level, which was variable of income per capita, profit sharing ratio, and lending rates for working capital 0.0695: 0.0612 and 0.9438. Moreover, It could be seen from the F test, which $F$ count $>$ F table for $59.2>3.49$.
\end{abstract}

Keywords: Income percapita, profit sharing ratio, lending rates for working capital, financing

\begin{abstract}
Abstrak
Penelitian ini adalah jenis penelitian yang bersifat deskriptif kuantitatif yang dilakukan pada 5 bank syariah di Indonesia yang berjudul "Analisis permintaan pembiayaan pada bank umum syariah di Indonesia periode 2006 - 2010”. Dari hasil diperoleh nilai koefisien determinasi (R2) untuk regresi data panel model Random effect sebesar 0,89. Hal ini berarti bahwa variabel-variabel bebas secara bersama-sama dapat menjelaskan $89 \%$ variasi variabel terikat, yaitu permintaan pembiayaan. Dari analisa data yang telah dilakukan secara serentak menunjukkan bahwa variabel pendapatan perkapita dan nisbah bagi hasil memiliki hasil yang lebih signifikan terhadap permintaan pembiayaan dari pada variable suku bunga kredit modal kerja. Hal ini dapat dilihat dari tingkat probabilitas atau signifikansinya, yaitu variabel pendapatan perkapita, nisbah bagi hasil dan suku bunga kredit modal kerja sebesar 0.0695; 0.0612 dan 0.9438. Selain itu juga dapat dilihat dari uji F, yang mana Fhitung > Ftabelsebesar 59,2 $>3,49$.
\end{abstract}

Kata Kunci: Pendapatan perkapita, nisbah bagi hasil, suku bunga kredit, pembiayaan 


\section{PENDAHULUAN}

Bank syariah merupakan lembaga keuangan yang melaksanakan perantara keuangan dari pihak-pihak yang kelebihan dana kepada pihak-pihak lain yang membutuhkan berdasarkan prinsipprinsip ajaran agama Islam, diantara prinsip-prinsip tersebut yang paling utama adalah tidak diperkenankannya perbankan untuk meminta atau memberikan bunga kepada nasabahnya (Idat, 2005). Bank syariah memiliki produk atau jasa yang tidak akan ditemukan dalam operasi bank konvensional. Prinsipprinsip seperti musyarakah, mudharabah, muarabahah, ijarah, istishna dan sebagainya tidak memuat adanya prinsip bunga seperti yang dikembangkan oleh bank konvensional.

Aturan ekonomi yang ada dalam Al Qur'an dan Al Hadits, jelas bahwa Islam benar-benar telah mengatur sistem ekonomi dengan teliti dan jelas melalui nilai nilainya yang universal, yaitu bahwa setiap transaksi ekonomi (muamalah) harus didasarkan pada asas kejujuran, keadilan, toleransi dan suka sama suka, baik dalam perdagangan, kerjasama (sharing) ataupun semua aspek ekonomi. Indikasinya bisa dilihat dari dibolehkannya sistem barter (materi dan manfaat), baik melalui jual beli, sewa menyewa, penggadaian, kerja sama dan lainnya. Islam juga telah memberikan kebebasan yang seluas - luasnya dalam melakukan transaksi ekonomi (selama tidak melanggar nilai-nilai universal Islam) bahkan menyuruh untuk terus dinamis dalam menciptakan kemudahan transaksi melalui beberapa instrumen agar selalu update dan valid dengan perubahan waktu dan tempat.

Dalam hal ini kegiatan bank syariah hampir sama dengan bank konvensional yaitu menghimpun dana dari masyarakat dimana dari seluruh dana $80 \%$ sampai $90 \%$ yang dikelola oleh pihak bank merupakan dana pihak ketiga baik berasal dari pemerintah, dunia usaha maupun masyarakat pada umumnya, sedangkan sisanya merupakan modal sendiri dan cadangan modal. Dana masyarakat merupakan sumber pembiayaan terbesar bagi bank. Hal ini dikaitkan dengan peranan bank sebagai perantara masyarakat dan agen pembangunan. Dana yang 
berasal dari simpanan masyarakat adalah sumber pembiayaan kredit terbesar bagi bank. Dan berdasarkan data bank Indonesia (BI), dana pihak ketiga (DPK) pada perbankan syariah mengalami peningkatan sebesar 40,83\% dari $\mathrm{Rp} 45,38$ triliun pada September 2009 menjadi Rp 63,91 triliun pada September 2010. Hal ini disebabkan karena semakin banyak promosi yang dilakukan oleh perbankan syariah. Selain promosi, perbankan syariah terus menerus melakukan perbaikan kualitas dan kuantitas sumber daya manusia.

Pada bank konvensional dalam mendapatkan keuntungan (Return) yang diperolehnya berupa bunga. Sedangkan bank syariah menggunakan istilah bagi hasil, yaitu proporsi bagi hasil antara nasabah dengan bank syariah. Bagi hasil adalah bentuk perolehan kembaliannya dari kontrak investasi, dari waktu ke waktu, tidak pasti dan tidak tetap. Besar kecilnya perolehan kembali itu bergantung pada hasil usaha yang bener-bener terjadi. Dengan demikian, dapat dikatakan bahwa system bagi hasil merupakan salah satu praktek perbankan syariah (adiwarman Karim, 199;2004).
Dari data Bank Indonesia (BI) menyatakan total asset perbankan syariah baru mencapai $\mathrm{Rp}$ 6,3 triliun atau 0,5 persen dari total asset perbankan konvensional. Sedangkan Bank Syariah Mandiri (BSM) memiliki asset $\mathrm{Rp}$ 3,1 triliun dan Dana Pihak Ketiga (DPK) Rp 2,3 triliun Asset Bank Muamalat Indonesia (BMI) mencapai $\mathrm{Rp} \mathrm{3,2}$ triliun dan DPK $\operatorname{Rp} 2,1$ triliun. Keadaan ini menunjukkan bahwa perkembangan/pertumbuhan perbankan syariah nasional belum sesuai dengan peluang yang ada. Hal ini disebabkan oleh beberapa kendala yang ada dalam pengembangan perbankan syariah. Utomo (2002) menyebutkan adanya kendala kultural dalam pengembangan perbankan syariah di Indonesia. Menurut Syafi'i Antonio (2001) kendala pengembangan bank syariah antara lain sumber daya manusia, belum terpenuhinya peraturan pemerintah di bidang perbankan syariah yang memadai, kurangnya akademisi perbankan syariah dan kurangnya sosialisasi ke masyarakat tentang keberadaan bank syariah.

Memperhatikan fungsi pokok perbankan sebagai lembaga yang 
mempunyai fungsi intermediasi keuangan/dana, dan manfaat yang besar bagi masyarakat (sektor riil), pembiayaan merupakan indikator utama untuk mengukur perkembangan/pertumbuhan pangsa pasar perbankan syariah, sehingga perlu dikaji faktor-faktor apa saja yang bisa mempengaruhi besarnya jumlah pembiayaan yang disalurkan ke masyarkat oleh sebuah lembaga keuangan (perbankan syariah).

Menurut Rose dan Kolari (1995) ada dua faktor yang mempengaruhi pendapatan lembaga keuangan yaitu faktor eksternal dan faktor internal. Faktor eksternal antara lain perubahan teknologi pengiriman jasa, kompetisi dari lembaga keuangan lainnya, hukum dan peraturan mengenai lembaga keuangan, dan kebijakan pemerintah yang mempengaruhi system ekonomi dan keuangan. Faktor internal antara lain efisiensi penggunaan sumber daya, pengendalian biaya, kebijakan manajemen perpajakan, posisi likuiditas, dan posisi risiko.

Menurut Muhammad (2004) faktor- faktor lingkungan secara umum dikelompokkan menjadi lingkungan umum dan lingkungan khusus. Faktor lingkungan umum yang mempengaruhi kinerja perbankan syariah antara lain kondisi politik, hukum, ekonomi, sosial dan budaya masyarakat, teknologi, kondisi lingkungan alamiah, dan keamanan lingkungan/negara. Faktor lingkungan khusus yang berpengaruh antara lain adalah pelanggan/nasabah, pemasok/penabung, pesaing, serikat pekerja, dan kebijakan bank sentral atau regulator. Sumber-sumber dana yang bisa digunakan untuk pembiayaan (loan) menurut RoseKolari (1995) adalah simpanan (giro, tabungan, deposito berjangka), pinjaman bank sentral (pinjaman liquiditas), pinjaman dari institusi keuangan internasional, dan modal ekuitas (modal disetor, laba ditahan cadangan).

Seperti Muhamad dan RoseKolari, penelitian ini menguji tingkat suku bunga dan tingkat pendapatan perkapita masyarakat sebagai faktorfaktor yang mempengaruhi jumlah pembiayaan yang disalurkan ke masyarakat oleh bank umum syariah di Indonesia. Penelitian ini bertujuan untuk mengetahui sejauh mana hubungan tingkat suku bunga dan pendapatan perkapita terhadap 
besarnya tingkat permintaan pembiayaan pada perbankan syariah di Indonesia.

\section{Tingginya}

pembiayaan oleh

permintaan

walaupun kebijakan kreditnya ketat (tingkat NPL rendah) maka permintaan pembiayaan tetap tinggi. Permintaan pembiayaan yang cukup tinggi ini bisa dilihat dari tingkat FDR bank syariah yang relatif tinggi, bahkan melebihi 100\% dibanding dengan tingkat LDR pada perbankan nasional. Kondisi ini menunjukkan bahwa posisi tawar Bank Muamalat Indonesia (BMI) lebih kuat dibanding dengan posisi nasabah atau calon nasabahnya.

Permintaan (pangsa pasar) pembiayaan di bank syariah cukup tinggi. Hal ini bisa dilihat dari tingkat Finance to Deposit Ratio (FDR) bank syariah yang bisa mencapai lebih $100 \%$, sebagai contoh laporan rasio keuangan BMI per 30 September 2004 seperti pada tabel di atas FDRnya $110,19 \%$. Meskipun ada kenaikan tingkat margin, pembiayaan yang disalurkan masih cukup tinggi karena tingginya permintaan pembiayaan oleh masyarakat, disisi lain tingkat margin yang ditetapkan masih mengacu pada tingkat rata-rata pasar perbankan.

Bank syariah menerapkan margin keuntungan terhadap produkproduk pembiayaan yang berbasis NCC (Natural Certainty Contract), yakni akad bisnis yang memberikan kepastian pembayaran, baik dari segi jumlah maupun waktu, seperti pembiayaan murabahah, ijarah, muntahia bit tamlik, salam, dan istishna. Penetapan besarnya margin keuntungan dilakukan dengan referensi margin keuntungan, yaitu margin keuntungan yang ditetapkan dalam rapat ALCO (Assets and Loans Committee) bank syariah (Karim, 2004). Penetapan margin keuntungan pembiayaan berdasarkan rekomendasi, usul dan saran dari Tim ALCO bank syariah, dengan mempertimbangkan beberapa hal yaitu Direct Competitor's Market Rate (DCMR), Indirect Competitor's Market Rate (ICMR), Expected Competitive return for Investors (ECRI), Acquiring Cos, dan Overhead Cost.

Bank syariah menerapkan nisbah bagi hasil terhadap produkproduk pembiayaan yang berbasis NUC (Natural Uncertainty Contract), 
yakni akad bisnis yang tidak dengan kata lain semakin tinggi memberikan kepastian pendapatan tingkat suku bunga maka akan baik dari segi jumlah maupun waktu, semakin sedikit jumlah permintaan seperti mudharabah dan musyarakah. pinjaman, dan sebaliknya. Jumlah Penetapan nisbah bagi hasil penawaran pembiayaan oleh bank pembiayaan ditentukan dengan berhubungan searah dengan tingkat mempertimbangkan referensi tingkat margin keuntungan dan perkiraan tingkat keuntungan bisnis/ proyek yang dibiayai. Referensi tingkat margin keuntungan adalah referensi tingkat margin keuntungan yang ditetapkan oleh rapat ALCO. Menurut Syafi'i Antonio (2001), Muhamad (2002), dan Karim (2004) tingkat biaya pembiayaan (margin keuntungan) berpengaruh terhadap jumlah permintaan pembiayaan syariah. Bila tingkat margin keuntungan lebih rendah daripada rata-rata suku bunga perbankan nasional, maka pembiayaan syariah semakin kompetitif.

Siamat (1993) dan Suyatno (2001) berpendapat bahwa tingkat suku bunga akan berpengaruh terhadap jumlah kredit di pasar perbankan. Menurut Rose dan Kolari (1995) jumlah permintaan pembiayaan/pinjaman (loan) oleh masyarakat berhubungan terbalik dengan tingkat suku bunga. Atau suku bunga, atau semakin tinggi tingkat suku bunga maka semakin tinggi pembiayaan yang ditawarkan.

Penelitian Kurniawan (2001: 61) menunjukkan bahwa suku bunga pinjaman mempunyai pengaruh yang signifikan positif terhadap penyaluran dana kredit usaha kecil oleh bankbank di Indonesia. Penelitian Sadwianto tersebut dengan data tahun 1992- 1997, dimana menurut penulis pada waktu itu posisi tawar nasabah (usaha kecil dan menengah) relatif lemah dibanding posisi tawar perbankan. Hal ini berbeda dengan kondisi sekarang dimana kompetisi industry perbankan relatif sangat tinggi dan nasabah relatif lebih kritis dan rasional dalam memilih sumbersumber pendanaan. Dengan demikian, semakin rendah tingkat margin yang diambil oleh bank syariah akan semakin besar pembiayaan yang diminta oleh masyarakat dan atau akan semakin besar pula pembiayaan yang dapat disalurkan oleh bank. 


\section{METODE PENELITIAN}

Variabel terikat dalam penelitian ini adalah tingkat permintaan pembiayaan, sedangkan variable Bebas dalam penelitian ini adalah Pendapatan Percapita Masyarakat $\left(\mathrm{X}_{1}\right)$, Nisbah Bagi Hasil $\left(\mathrm{X}_{2}\right)$, dan Tingkat Suku Bunga $\left(\mathrm{X}_{3}\right)$.

Ada tiga teknik yang bisa digunakan dalam regresi data panel yang digunakan dalam penelitian ini yaitu teknik OLS (Common Effect), Fixed Effect dan Random Effect. Untuk menentukan teknik yang paling tepat untuk mengestimasi regresi data panel, harus melalui tiga uji yaitu uji F, uji LM, dan uji Hausman. Adapun alat analisa yang digunakan dalam penelitian ini adalah untuk mencari pengaruh antara variabel - variabel bebas terhadap variabel terikat digunakan model analisa regresi linear berganda dengan rumus sebagai berikut:

$\mathrm{Y}=\beta 0+\beta_{1} \mathrm{X} 1+\beta_{2} \mathrm{X} 2+\beta_{3} \mathrm{X} 3+\mathrm{e}$

Dimana: $\mathrm{Y}=$ Permintaan

Pembiayaan; $\mathrm{X}_{1}=$ Pendapatan Perkapita; $X_{2}=$ Nisbah Bagi Hasil; $X_{3}$ = Suku Bunga Kredit Modal Kerja.

\section{PEMBAHASAN}

Berdasarkan hasil regresi teknik Random Effect maka diperoleh hasil: $\mathrm{Y}_{\mathrm{it}}=$ Random Effect $-0,216 \mathrm{X}_{1}+$ $0,260 X_{2}+0,011 X_{3}+e_{i t}$

Ada tiga uji yang digunakan untuk menentukan teknik yang paling tepat untuk mengestimasi regresi data panel. Tiga uji tersebut yaitu uji statistik F, uji Lagrange Multiplier (LM) dan uji Hausman.

Pertama, Uji Statistik F, Untuk mengetahui signifikansi teknik Fixed Effect akan diuji menggunakan uji statistik F. Kegunaan uji statistik F yaitu untuk memilih antara metode OLS (Common Effect) tanpa variabel dummy atau metode Fixed Effect. Berdasarkan Numerator $=4$ dan denumerator $=25-4=21$, pada $\alpha=$ $5 \%(0,05)$ diperoleh nilai $\mathrm{F}$ tabel $=$ 2,87. Dari hasil uji F diperoleh nilai F hitung sebesar 10,880 jadi nilai $F$ hitung $(10,880) \geq F$ tabel $(2,87)$. Maka dapat disimpulkan bahwa Ho ditolak dan Ha diterima, berarti model Fixed Effect merupakan model yang tepat.

Kedua, Uji Lagrange Multiplier (LM), Menurut Widarjono (2005), untuk mengetahui signifikansi teknik Random Effect akan diuji 
menggunakan uji Lagrange Multiplier (LM). Uji Lagrange Multiplier (LM) digunakan untuk memilih antara OLS (Common Effect) tanpa variabel dummy atau Random Effect. Uji signifikansi Random Effect ini dikembangkan oleh Bruesch-pagan. Nilai df sebesar 3 pada $\alpha=5 \%(0,05)$ diperoleh nilai $\mathrm{X}^{2}$ tabel sebesar 7.81473. Dari hasil uji Lagrange Multiplier (LM), diperoleh nilai LM hitung sebesar 160,914. Jadi nilai LM hitung $(160,914) \geq X^{2}$ tabel $(7.81473)$ maka dapat disimpulkan bahwa Ho ditolak dan Ha diterima, berarti model Random Effect merupakan model yang tepat.

Ketiga, Uji Hausman. Dari hasil uji signifikansi dua teknik di atas, diperoleh hasil bahwa teknik yang paling tepat yaitu Fixed Effect dan Random Effect. Untuk memilih antara teknik Fixed Effect atau Random Effect maka akan diuji kembali dengan uji Hausman. Kegunaan uji Hausman yaitu untuk memilih antara Fixed Effect atau Random Effect.

Tabel 1. Ranking Intercept Pada Teknik Random Effect

\begin{tabular}{clc}
\hline Rangking & \multicolumn{1}{c}{ Bank Umum Syariah } & Intercept \\
\hline 1 & Bank Syariah Mandiri & 0.968933 \\
2 & Bank Muamalat & 0.911464 \\
3 & BRI Syariah & -0.084918 \\
4 & BNI Syariah & -0.305573 \\
5 & Mega Syariah & -1.489906 \\
\hline
\end{tabular}

Sumber : Data Diolah

Uji Hausman digunakan apabila metode Fixed Effect dan Random Effect lebih baik dari metode OLS (Common Effect). Nilai df sebesar 4, pada $\alpha=5 \%(0,05)$ diperoleh nilai $X^{2}$ tabel sebesar 7,815. Dari hasil olah data Hausman hitung dengan menggunakan program Eviews diperoleh nilai Hausman hitung sebesar 7,662. Jadi Hausman hitung $(7,662) \leq \mathrm{X}^{2}$ tabel $(7,815)$ maka dapat disimpulkan bahwa Ho diterima dan Ha ditolak, berarti model Random Effect merupakan model yang tepat.

Dari model persamaan regresi tersebut diperoleh nilai intercept atau konstanta sebesar $\alpha$ (karena regresi dalam bentuk Random Effect, maka intercept disajikan dengan menunjukkan intercept per Perbankan umum syariah di indonesia). Hal ini berarti bahwa variabel profitabilitas 
(Y) sebesar nilai intercept masingmasing bank umum syariah pada saat variabel Pendapatan Perkapita $\left(\mathrm{X}_{1}\right)$, Nisbah Bagi Hasil $\left(\mathrm{X}_{2}\right)$, dan Suku Bunga Kredit Modal Kerja $\left(\mathrm{X}_{3}\right)$ sebesar nol (konstan).

Nilai intercept berbeda pada masing-masing bank go public menunjukkan keunikan model tersebut. Di bawah ini disajikan intercept masing-masing Perbankan di Indonesia berdasarkan rankingnya, pada teknik Random Effect.

Intercept tertinggi (ranking pertama) dicapai oleh Bank Syariah Mandiri dengan nilai intercept atau konstanta sebesar 0.968933, berarti tingkat permintaan pembiayaan $(\mathrm{Y})=$ 9,3096 Intercept ranking kedua dicapai oleh Bank Muamalat dengan nilai intercept atau konstanta sebesar 0.911464 , berarti nilai permintaan pembiayaan $(\mathrm{Y})=8,1557$ Intercept ranking ketiga dicapai oleh BRI Syariah dengan nilai intercept atau konstanta sebesar -0.084918 , berarti nilai permintaan pembiayaan $(\mathrm{Y})=$ 0,8223 Intercept ranking keempat dicapai oleh BNI Syariah dengan nilai intercept atau konstanta sebesar 0.305573 , berarti nilai permintaan pembiayaan $(\mathrm{Y})=0,4947$ Intercept ranking kelima dicapai oleh Bank Mega Syariah dengan nilai intercept atau konstanta sebesar -1.489906, berarti nilai permintaan pembiayaan $(\mathrm{Y})=0,0323$.

Berdasarkan penjelasan di atas maka dapat diketahui Bank Muamalat memiliki nilai intersep tertinggi, karena Bank Muamalat memiliki kemampuan untuk meningkatkan permintaan pembiayaan Bank umum syariah.

Adapun koefisien regresi variabel pendapatan perkapita (PPK) $\left(X_{1}\right)$ sebesar - 0,216 berarti ada pengaruh negatif antara PPK terhadap permintaan pembiayaan sebesar 0,216. Jadi apabila PPK naik $1 \%$, maka permintaan pembiayaan akan turun sebesar 21.6\%. Sebaliknya, apabila PPK turun sebesar $1 \%$ maka permintaan pembiayaan akan naik sebesar $21.6 \%$ dengan asumsi variabel lain konstan. Koefesien regresi variabel untuk nisbah bagi hasil $(\mathrm{NBH})\left(\mathrm{X}_{2}\right)$ sebesar 0,260 berarti ada pengaruh positif antara NBH terhadap permintaan pembiayaan sebesar 0,260. Jadi apabila NBH naik $1 \%$, maka permintaan pembiayaan naik sebesar $26 \%$. Sebaliknya, NBH turun sebesar $1 \%$ maka permintaan 
pembiayaan turun sebesar 26\% dengan asumsi variabel lain konstan. Koefesien regresi variabel untuk suku bunga kredit modal kerja (SBKMK) $\left(\mathrm{X}_{3}\right)$ sebesar 0,011 berarti ada pengaruh positif antara SBKMK terhadap permintaan pembiayaan sebesar 0,011. Jadi apabila SBKMK naik $1 \%$, maka permintaan pembiayaan naik sebesar $1,1 \%$. Sebaliknya, SBKMK turun sebesar $1 \%$ maka permintaan pembiayaan turun sebesar $1,1 \%$ dengan asumsi variabel lain konstan.

Pengujian hipotesis dilakukan untuk mengetahui ada tidaknya pengaruh secara nyata hubungan variabel bebas terhadap variabel terikat baik secara simultan maupun parsial. Pengujian hipotesis ada dua macam yaitu uji parsial (uji t) dan uji simultan (ujiF). Uji $t$ ini digunakan bertujuan untuk melihat secara parsial pengaruh dari masing-masing variabel independent $\left(\mathrm{X}_{1}\right),\left(\mathrm{X}_{2}\right)$, dan
$\left(\mathrm{X}_{3}\right)$ terhadap variabel dependent (Y). Jika $t_{\text {hitung }}<t_{\text {tabel }}$ maka Ho diterima dan Ha ditolak, berarti tidak ada pengaruh antara variabel independent dan variabel dependent tidak signifikan. Dan sebaliknya, jika $t_{\text {hitung }}>t_{\text {tabel }}$ maka Ho ditolak dan Ha diterima, berarti ada pengaruh antara variabel independent dengan variabel dependent adalah signifikan.

Berdasarkan hasil perhitungan di atas dapat dilakukan pengujian pada masing-masing variabel bebas sebagai berikut : Pertama, Variabel Pendapatan Perkapita $\left(\mathrm{X}_{1}\right)$. Variabel Pendapatan Perkapita $\left(\mathrm{X}_{1}\right)$ memiliki nilai t hitung sebesar -1.912849 dan nilai probabilitas sebesar 0.0695 . Hal ini berarti nilai $t$ hitung sebesar (1.912849) > t tabel (1.721) maka Ho ditolak dan Ha diterima, dengan demikian dapat disimpulkan bahwa variabel Pendapatan Perkapita $\left(\mathrm{X}_{1}\right)$ secara parsial berpengaruh signifikan terhadap Permintaan Pembiayaan.

Tabel 2. Hasil Uji T

\begin{tabular}{ccccc}
\hline Variable & Coefficient & t-Statistic & t-tabel & Prob. \\
\hline PPK & -0.216354 & -1.912849 & 1.721 & 0.0695 \\
NBH & 0.260888 & 1.978345 & 1.721 & 0.0612 \\
SBKMK & 0.011098 & 0.071333 & 1.721 & 0.9438
\end{tabular}

Sumber: Data Diolah 


\section{Gambar 1. Uji T untuk Pendapatan Perkapita}

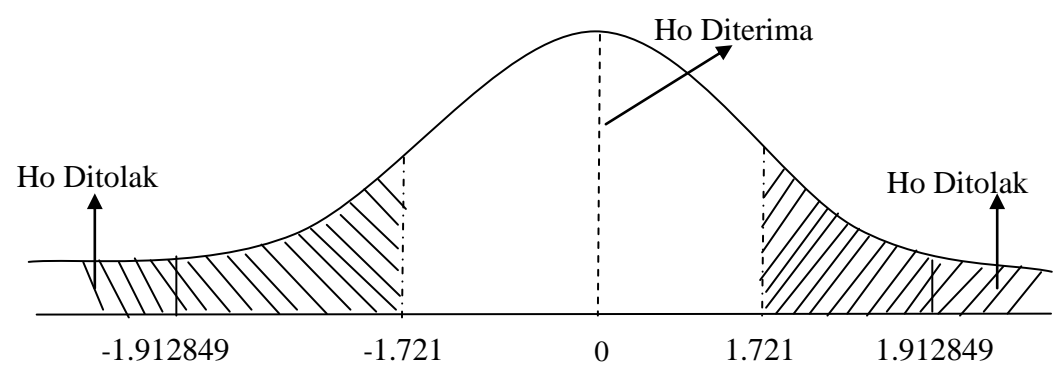

Sumber: Data Diolah

\section{Gambar 2. Uji T untuk Nisbah Bagi Hasil}

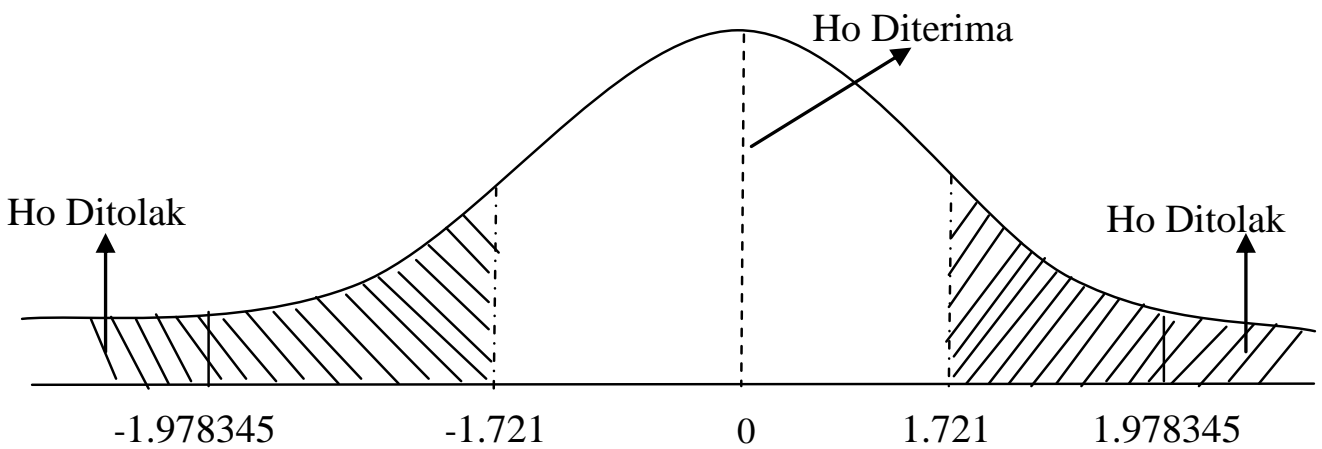

Sumber: Data Diolah

\section{Gambar 3. Uji T untuk Suku Bunga Kredit Modal Kerja}

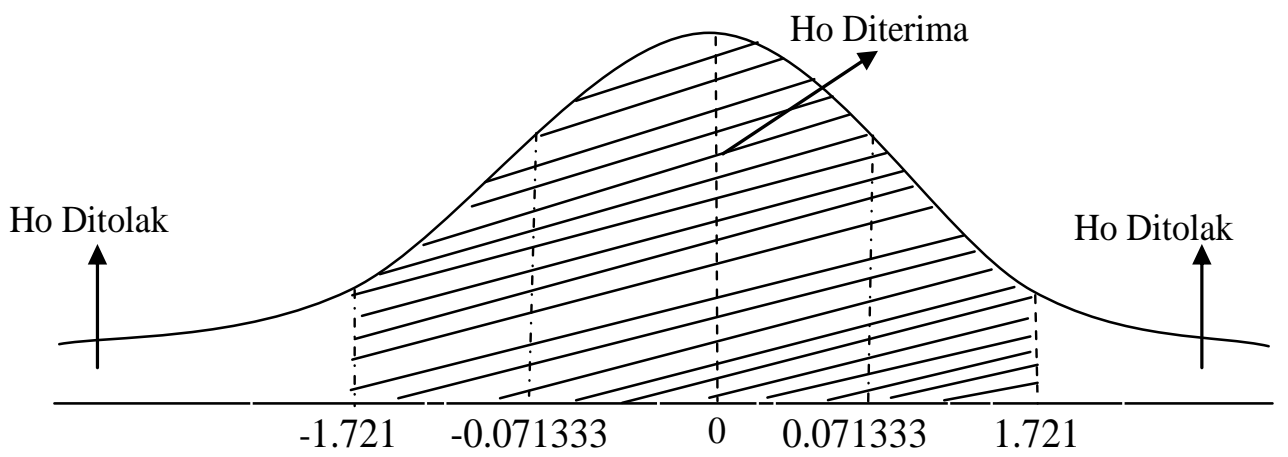

Sumber: Data Diolah

Kedua, Variabel Nisbah Bagi diterima dan Ha ditolak, dengan Hasil $\left(\mathrm{X}_{2}\right)$ memiliki nilai $\mathrm{t}$ hitung demikian dapat disimpulkan bahwa sebesar 1.978345 dan nilai variabel Nisbah Bagi Hasil $\left(\mathrm{X}_{2}\right)$ probabilitas sebesar 0.0612. Hal ini secara parsial tidak berpengaruh berarti nilai $t$ hitung sebesar signifikan terhadap Permintaan $1.978345>\mathrm{t}$ tabel (1.721) maka Ho Pembiayaan. 
Ketiga, Variabel Suku Bunga Kredit Modal Kerja $\left(\mathrm{X}_{3}\right)$ memiliki nilai $\mathrm{t}$ hitung sebesar $0.071333 \mathrm{dan}$ nilai probabilitas sebesar 0.9438 . Hal ini berarti nilai $t$ hitung sebesar $0.071333<\mathrm{t}$ tabel $(1.721)$ maka Ho diterima dan $\mathrm{Ha}$ ditolak, dengan demikian dapat disimpulkan bahwa variabel Suku Bunga Kredit Modal Kerja $\left(X_{3}\right)$ secara parsial tidak berpengaruh signifikan terhadap Permintaan Pembiayaan.

Uji $F$ merupakan pengujian untuk mengetahui ada tidaknya pengaruh secara simultan (serentak) antara seluruh variabel bebas
(Pendapatan Perkapita, Nisbah Bagi Hasil dan Suku Bunga Kredit Modal Kerja) terhadap variabel terikat Permintaan Pembiayaan. Nilai $\mathrm{df}_{1}$ sebesar 3, dan $\mathrm{df}_{2}=\mathrm{n}-\mathrm{k}-1=25-3-$ $1=21$ atau df $(3,21)$ pada $\alpha=10 \%$ $(0,10)$ diperoleh nilai $\mathrm{F}$ tabel sebesar 2,38. Nilai $F_{\text {hitung }}>F_{\text {tabel }}(59,2>$ 2,38). Maka dapat ditarik kesimpulan bahwa Ho ditolak, ha diterima artinya variabel Pendapatan Perkapita, Nisbah Bagi Hasil dan Suku Bunga Kredit Modal Kerja berpengaruh secara serentak atau bersama-sama terhadap Permintaan Pembiayaan dengan hasil yang signifikan.

\section{Gambar 4. Uji F}

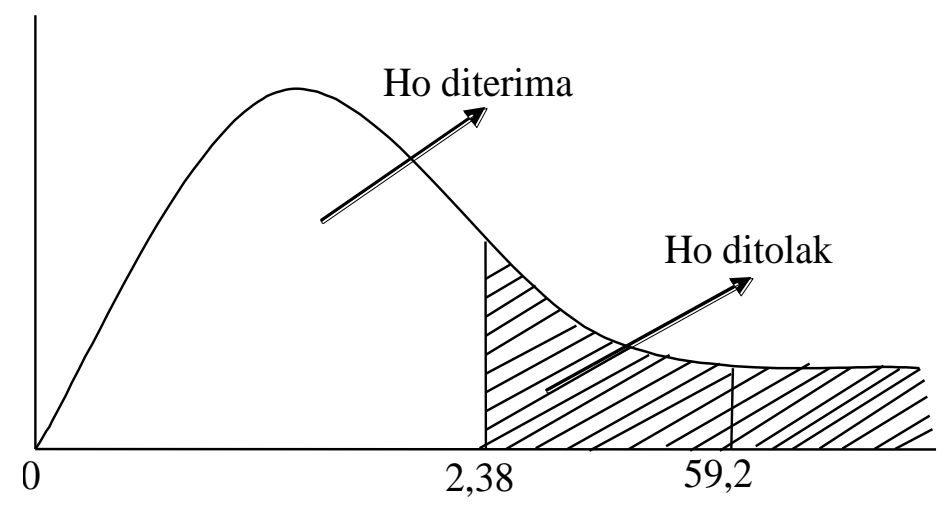

Sumber: Data Diolah

Koefisien determinasi $\left(\mathrm{R}^{2}\right) \quad$ mendekati 1 maka dapat diyatakan digunakan untuk mengetahui model semakin baik. Koefisien kontribusi variabel bebas terhadap determinasi $\left(\mathrm{R}^{2}\right)$ sebesar 0.89 atau 89 variabel terikat. Nilai $\mathrm{R}^{2}$ besarnya $\%$. Hal ini berarti kemampuan antara $0<\mathrm{R}^{2}<1$, dimana semakin variabel bebas yang terdiri dari 
Pendapatan Perkapita, Nisbah Bagi Hasil dan Suku Bunga Kredit Modal Kerja dalam menjelaskan variabel terikat (Permintaan Pembiayaan) sebesar 0.89 (89\%), sedangkan sisanya $11 \% \quad(1-0.89=0.11)$ dijelaskan oleh variabel lain diluar model yang secara implisit tercermin pada variabel pengganggu.

Berdasarkan hasil regresi, maka hubungan pendapatan perkapita dengan permintaan pembiayaan adalah berbanding terbalik (negatif). Jika pendapatan perkapita masyarakat rendah maka tingkat permintaan pembiayaan akan naik dan sebaliknya apabila pendapatan perkapita masyarakat tinggi maka tingkat permintaan pembiayaan akan menurun. Hal ini menggambarkan bahwa jika pendapatan masyarakat meningkat maka daya beli masyarakat juga akan meningkat sehingga akan menurunkan tingkat permintaan pembiayaan.

Hubungan nisbah bagi hasil dengan permintaan pembiayaan adalah positif. Jika nisbah bagi hasil rendah maka tingkat permintaan pembiayaan akan menurun dan sebaliknya apabila nisbah bagi hasil tinggi maka tingkat permintaan pembiayaan akan naik. Hal ini menggambarkan bahwa Mudharib (Nasabah) akan melihat proporsi nisbah bagi hasil yang akan mereka dapat sebelum melakukan permohonan pembiayaan, sehingga jika proporsi mudharib rendah maka keinginan akan permintaan pembiayaan akan menurun. Dan jika nisbah bagi hasil tinggi maka akan mendorong mudharib melakukan permohonan permintaan pembiayaan.

Hubungan Suku Bunga Kredit Modal Kerja dengan permintaan pembiayaan adalah positif. Jika Suku Bunga Kredit Modal Kerja rendah maka tingkat permintaan pembiayaan akan menurun dan sebaliknya apabila Suku Bunga Kredit Modal Kerja tinggi maka tingkat permintaan pembiayaan akan naik. Hal ini menunjukkan bahwa Mudharib (Nasabah) akan melihat tingkat suku bunga dan membandingkan dengan tingkat nisbah bagi hasil, jika tingkat suku bunga lebih tinggi dibanding dengan tingkat nisbah bagi hasil maka Mudharib akan beralih kepada nisbah bagi hasil pembiayaan pada bank syariah, dan jika tingkat suku bunga lebih rendah dibandingkan nisbah bagi hasil pembiayaan maka 
mudharib akan memilih bank konvensional dalam permohonan kreditnya sehingga akan menurunkan tingkat permintaan pembiayaan pada bank syariah.

\section{PENUTUP}

Perkembangan

tingkat permintaan pembiayaan pada tahun 2006 - 2010 bank syariah mandiri, bank muamalat dan BRI syariah selalu mengalami peningkatan. Untuk tingkat permintaan pembiayaan pada bank mega syariah tahun 2006 - 2010 nilainya berfluktuasi. Untuk bank BNI Syariah tingkat permintaan pembiayaan pada tahun 2006 - 2008 selalu mengalami peningkatan, namun dari tahun 2008 ke 2009 mengalami penurunan dan pada tahun 2010 kembali mengalami peningkatan. Adapun perkembangan tingkat bagi hasil bank syariah mandiri dan BRI Syariah selalu mengalami peningkatan, nisbah bagi hasil bank muamalat nilainya berfluktuasi dari tahun 2006 - 2010 . Untuk nisbah bagi hasil Bank Mega Syariah dari tahun 2006 - 2010 selalu mengalami penurunan, untuk bank BNI Syariah tingkat nisbah bagi hasil nilainya konstan dari tahun 2006 2010.
Bahwa dalam penyaluran dana (pembiayaan) bank umum syariah mengalami kenaikan dari tahun 20062010, Itu menunjukan bahwa kinerja bank umum syariah di Indonesia dalam keadaan stabil. Adapun Intercept tertinggi (ranking pertama) dicapai oleh Bank Muamalat dengan nilai intercept sebesar 0.911.464. Intercept ranking kedua dicapai oleh Bank Syariah Mandiri dengan nilai intercept sebesar 0.968.933. Intercept ranking ketiga dicapai oleh BRI Syariah dengan nilai intercept sebesar -0.084.918. Intercept ranking keempat dicapai oleh BNI Syariah dengan nilai intercept sebesar -0.305 .573 . Intercept ranking kelima dicapai oleh Bank Mega Syariah dengan nilai sebesar 1.489.906.

\section{DAFTAR PUSTAKA}

Ascarya. 2008. Akad dan Produk Bank Syariah. PT Raja Grafindo Persada. Jakarta.

Gujarati, Damodar N. dan Dawn C. Porter. 2010. Dasar - Dasar Ekonometrika. Edisi Lima. Salemba Empat. Jakarta.

Hasibuan, Malayu S.P. 2004. DasarDasar Perbankan. Bumi Aksara. Jakarta.

Kasmir. 2005. Dasar - Dasar Perbankan. PT Raja Grafindo Persada. Jakarta. 
Laksmana, Yusak. 2009. Accaount Officer Bank Syariah. Gramedia. Jakarta.

Mudrajad, Kuncoro dan Suhardjono. 2002. Manajemen Perbankan Teori dan Aplikasi. Edisi satu. BPFE. Yogyakarta.

Siamat, Dahlan. 2005.Manajemen Lembaga Keuangan, Kebijakan Moneter, dan Perbankan. Edisi Lima.
Lembaga Penerbit FE Universitas Indonesia. Jakarta

Sudarsono, Heri. 2002. Konsep Ekonomi Islam: suatu pengantar. Edisi Satu. Ekonisia. Yogyakarta.

Sumodiningrat, Gunawan. 1994. Ekonometrika Pengantar. Edisi pertama. BPFE. Yogyakarta.

www.bi.go.id . Diakses pada tanggal 15 Juli 2011. 